\title{
Palynomorph assemblage biozonation of Paleogene strata in Bende-Umuahia Area, Niger Delta Basin, southeastern Nigeria
}

Okechukwu Nicodemus Ikegwuonu 1*, Obianuju Patricia Umeji², Osita Igwebuike Chiaghanam', Kingsley K. Nwozor ${ }^{1}$, Otobong Sunday Ndukwe ${ }^{3}$ and Kingsley Chukwuebuka Chiadikobi ${ }^{1}$

\begin{abstract}
Cenozoic sediments form extensive outcrops in the Niger Delta Basin. Detailed palynostratigraphic study was undertaken across Paleogene sequences exposed in Bende-Umuahia Area in up-dip sectors of the Niger Delta Basin, southeastern Nigeria, to establish different palynomorphs assemblage zones, with their corresponding ages. Palynological analysis was carried out on 27 selected outcrop samples, using the conventional maceration technique for recovering acid-insoluble organic-walled microfossils from sediments. Three Cenozoic lithostratigraphic units, including Imo Formation, Ameki Formation, and Ogwashi Formation, are exposed in the study area. Lithologies are sandstone, carbonaceous shale, mudstone, limestone, and the lignite. A total of 65 species of sporomorphs and 51 dinoflagellate cysts were identified. The recovered spores and pollen grains were used to establish six informal palynomorph assemblage zones, labeled as zone A - zone F, based on the first and the last occurrences of two or more species. These palynomorph assemblage zones include: (1) zone A - middle Paleocene Scabratriporites simpliformis-Bombacidites annae zone; (2) zone B - late Paleocene Foveotricolporites crassiexinus-Mauritidites crassiexinus zone; (3) zone C - early Eocene Striatopollis catatumbus-Momipites africanus zone; (4) zone D - middle Eocene Margocolporites umuahiaensis-Gemmastephanocolporites brevicolpites zone; (5) zone E - late Eocene Cicatricosisporites dorogensis-Perfotricolpites nigerianus zone; and, (6) zone F - Oligoceneearly Miocene Verrucatosporites usmensis-Magnastriatites howardii zone. The erected palynozones were correlated and compared with existing biozones in subsurface, down-dip sectors of the Niger Delta Basin, with pantropical palynological zones in tropical areas of Africa, and with palynofloral provinces of northern South America. A comparison of palynozones studied in southeastern Nigeria with other international palynozones, in this study, will assist in establishing the correlation of sediments for these areas.
\end{abstract}

Keywords: Palynology, Stratigraphy, Biozonation, Spores and pollen grains, Dinoflagellate cysts, Cenozoic, Niger Delta Basin

\section{Introduction}

Cenozoic palynostratigraphic data available for research on the Niger Delta Basin mostly focused on subsurface, down-dip sectors of the basin (Fig. 1). Among pioneering research, Germeraad et al. (1968) covered extensively

\footnotetext{
* Correspondence: okeynick2010@yahoo.com

'Department of Geology, Chukwuemeka Odumegwu Ojukwu University, Uli, Nigeria

Full list of author information is available at the end of the article
}

the palynostratigraphy of Cenozoic sediments from the tropical areas of West Africa, northern South America to Sumatra and Borneo, and erected three main zonal divisions according to their lateral extent. They used data of pollen and spores to establish six pantropical palynozones, which from base to top were recognized as: (1) the Paleocene Proxapertites operculatus zone; (2) the Eocene Monoporites annulatus zone; (3) the late Eocene Verrucatosporites usmensis zone; (4) the Oligocene 


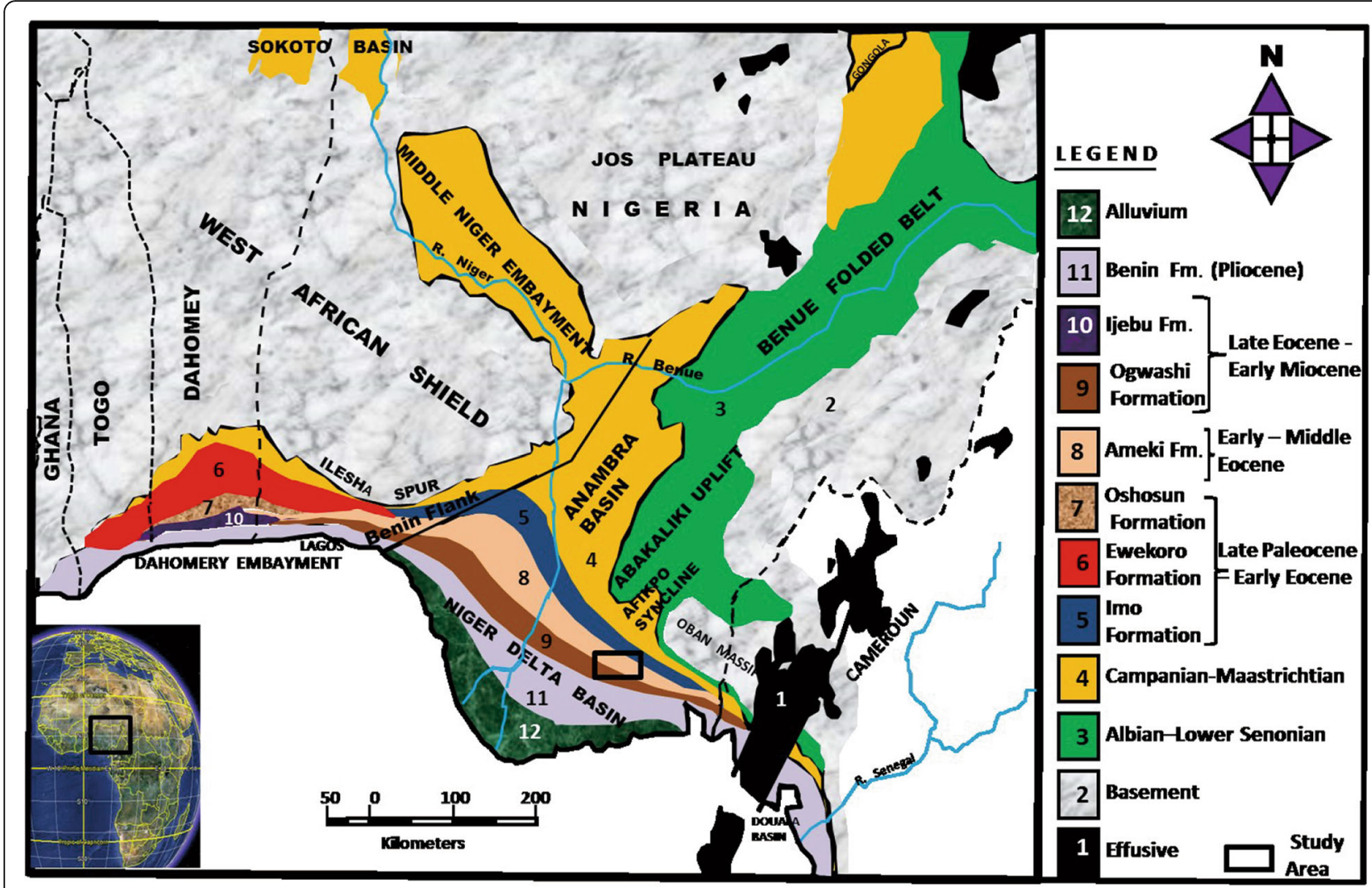

Fig. 1 General geological map and Cenozoic succession of the Niger Delta Basin and the location of the study area (modified after Murat 1972). Fm. = Formation; R. = River

Magnastriatites howardi zone; (5) the Miocene Crassoretitriletes vanraadshoveni zone; and, (6) the Pliocene Echitricolporites spinosus zone. Van Hoeken-Klinkenberg (1966) documented the occurrence of some late Paleocene-early Eocene sporomorphs of Nigeria, including Retitricolpites clarensis, Psilatricolporites medius, Retitricolpites marginatus, Retitricolporites ellipticus, Retistephanocolpites irregularis, Retibrevitricolpites triangulatus, and Proxapertites cursus. Other descriptions of Cenozoic palynostratigraphic data include Evamy et al. (1978), Legoux (1978), Sowunmi (1987), Oboh et al. (1992), Ojo and Salami (1992), Oboh (1995), Ojo and Adebayo (2001), Ige (2009), Durugbo et al. (2010), Lucas and Ishiekwene (2010), Adebayo et al. (2012), and, Aturamu et al. (2015). The planktonic foraminifer zonation and the calcareous nanofossil biozones of the subsurface Niger Delta have also been established by Martini (1971).

However, in the inland part of the Niger Delta Basin, work has focused on the macrofauna and foraminifera biostratigraphy, while little attention was given to palynological biostratigraphy. Notable palynostratigraphic studies include the work of Jan du Chêne et al. (1978), who reported some new Eocene pollen from the Ogwashi Formation, and other recent work by Umeji (2002, 2003), Oboh-Ikuenobe et al.
(2005), Chiaghanam et al. (2014), Umeji and Nwajide (2014), Ikegwuonu and Umeji (2016) and Okeke and Umeji (2016), whose work focused on the age and palaeoenvironments of outcropping sediments of the Niger Delta Basin. Ikegwuonu and Umeji (2016) documented the palynological age and the depositional palaeoenvironment of the Mid-Cenozoic sediments around Umuahia in the Niger Delta Basin, southeastern Nigeria. They argued that the recovered index sporomorphs, including Verrucatosporites usmensis, Magnastriatites howardii, Retibrevitricolporites obodoensis, Retibrevitricolporites ibadanensis, Psilatricolporites crassus, Echiperiporites icacinoides, Echiperiporites minor, Retibrevitricolporites protrudens, Chenopodipollis disperses and Retitricolporites irregularis, could represent the Oligocene-early Miocene Verrucatosporites usmensis/Magnastriatites howardii pantropical palynozone of Germeraad et al. (1968). Okeke and Umeji (2016) studied palynostratigraphy, palynofacies and depositional palaeoenvironments of the Selandian-Aquitanian sediments along the Onitsha-Awka transect in the Niger Delta Basin, southeastern Nigeria. They interpreted the Imo Formation to have been generally deposited in shallow waters of the inner and coastal zone, whereas the overlying Nanka Formation was deposited under 
alternating coastal and inner neritic conditions, and the Ogwashi Formation was deposited under oscillating coastal plain and brackish water conditions. These previous studies, however, focused mostly on the age of deposition, palaeoecology, and palaeoenvironment of the formations, whereas no significant attention was paid to palynomorph biozonation of the inland part of the basin.

This study, therefore, attempts to document, for the first time, the palynomorph assemblage biozonation of the Paleogene up-dip outcropping strata in Bende-Umuahia Area, Niger Delta Basin, southeastern Nigeria. As more studies develop, new results are added to the existing database, and tie in the current results from the up-dip outcropping strata of the basin to results from the subsurface, in order to develop a basin-wide regional correlation.

The study area covers approximately $235 \mathrm{~km}^{2}$ between latitudes of $5^{\circ} 27^{\prime} \mathrm{N}-5^{\circ} 40^{\prime} \mathrm{N}$ and longitudes of $7^{\circ} 25^{\prime} \mathrm{E}-7^{\circ} 43^{\prime}$ E, within the Niger Delta Basin in southeastern Nigeria (Fig. 2). Three Cenozoic formations, including the Imo Formation, the Ameki Formation and the Ogwashi Formation, outcrop in the study area (Figs. 1 and 2).

\section{Geological setting and stratigraphy}

Geographically, the Niger Delta Basin is located between latitudes of $3^{\circ} \mathrm{N}$ and $6^{\circ} \mathrm{N}$ and longitudes of $5^{\circ} \mathrm{E}$ and $8^{\circ} \mathrm{E}$, and occupies the continental margin of the Gulf of Guinea in equatorial West Africa (Fig. 1). It has a total area of about $75,000 \mathrm{~km}^{2}$ and an entirely clastic sedimentary-fill up to $12,000 \mathrm{~m}$ thick (Reijers et al. 1997). The fill was supplied by large continental drainage systems which constructed arcuate and bird-foot deltaic wedges prograde basinward into the oceanic crusts (Short and Stauble 1967).

Paleogene sediments including the Imo, Ameki, and Ogwashi Formations were regarded as a part of the Afikpo Basin by the previous research in the region (Reyment 1965; Arua 1986; Arua and Rao 1987; Oboh-Ikuenobe et al. 2005). These sediments are separated from the Campano-Maastrichtian stages developed in Anambra and Afikpo Basins based on dating results. The Imo, Ameki, and Ogwashi Formations have similar microfloral assemblages with those in the subsurface Niger Delta. These formations form the up-dip series of the Niger Delta Basin and are the lateral equivalents of the down-dip Akata and Agbada Formations (Fig. 3).

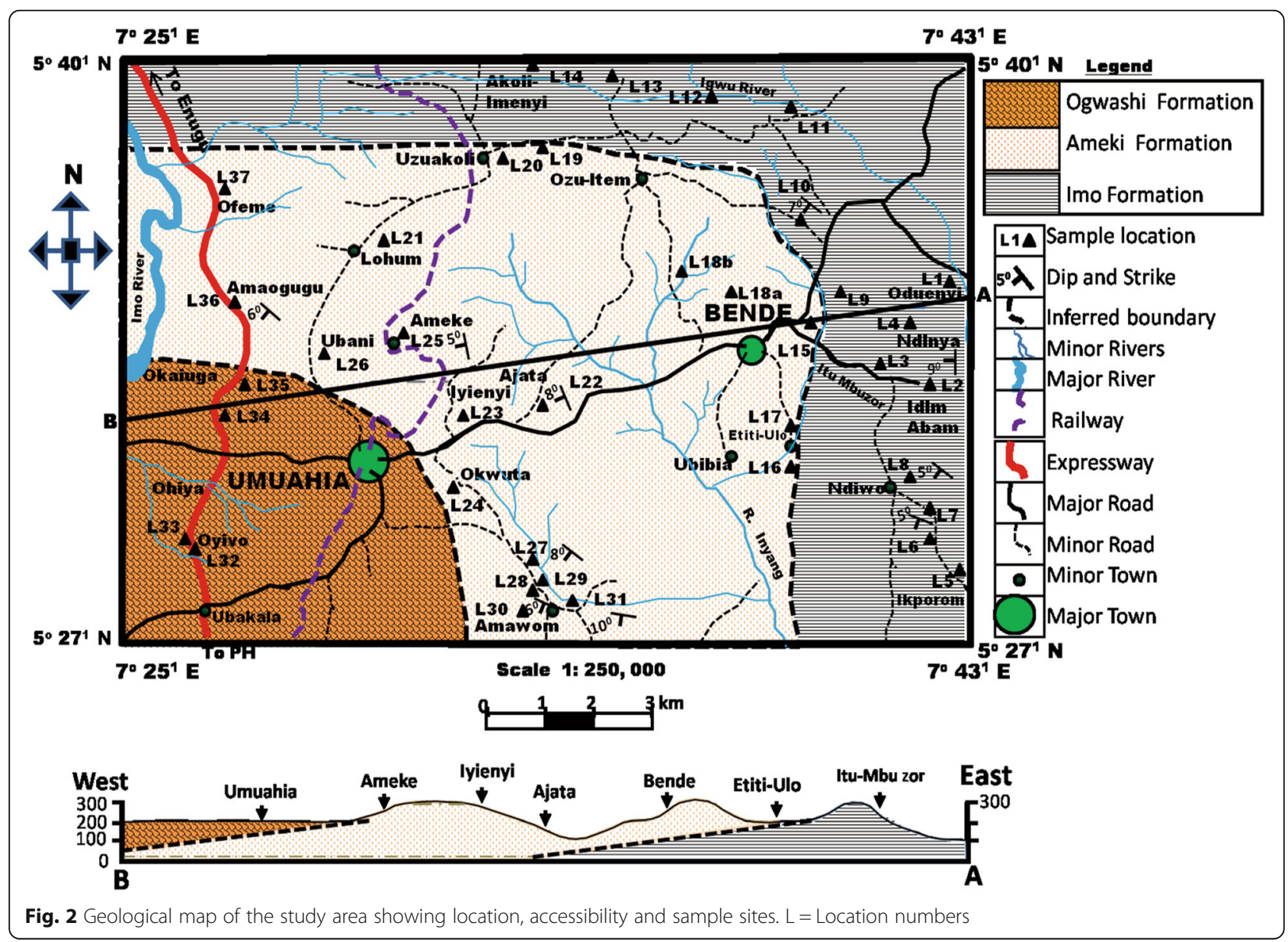




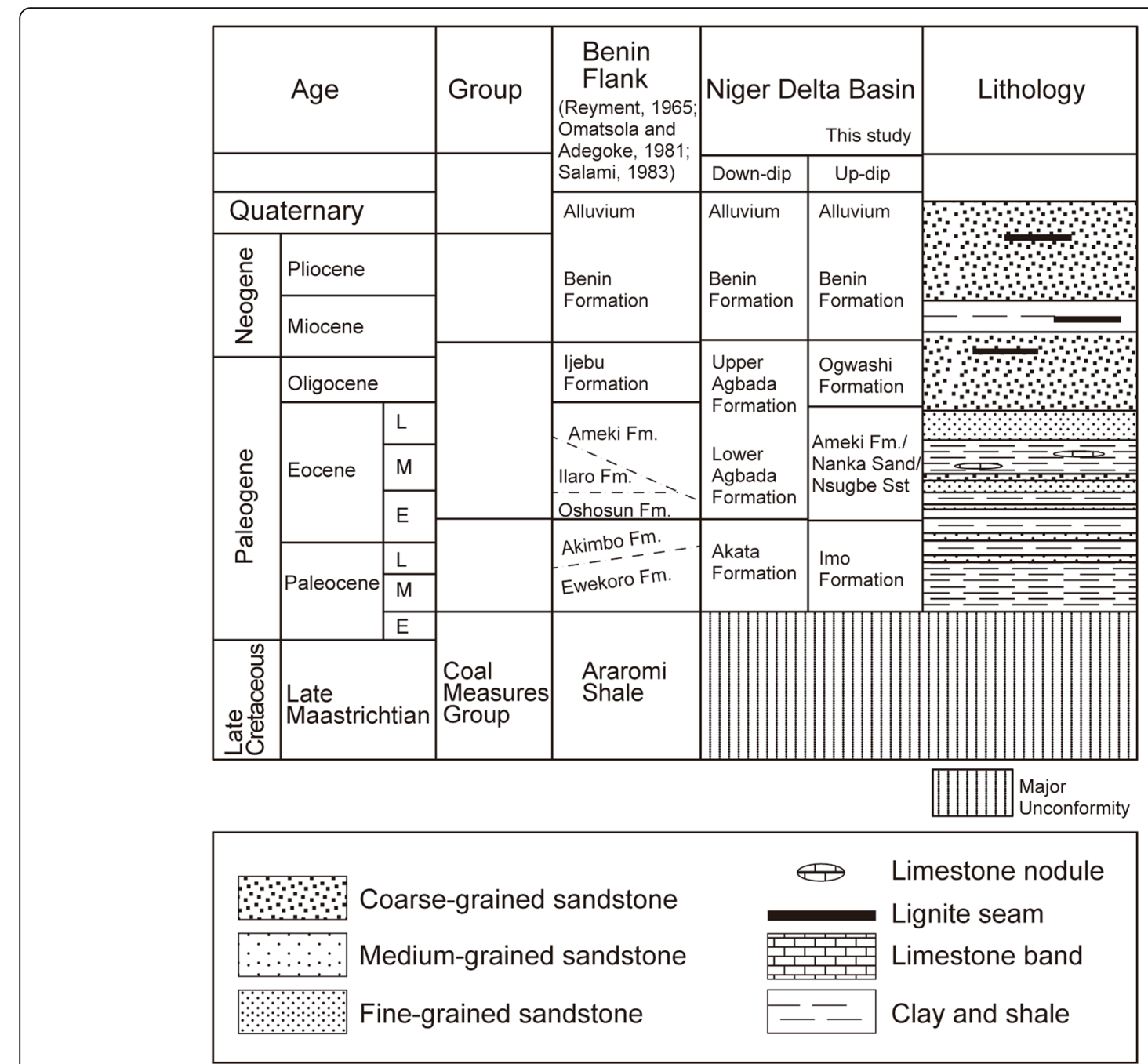

Fig. 3 Stratigraphic column of Niger Delta Basin and other coastal basins in Nigeria (according to Reyment 1965; Omatsola and Adegoke 1981; Salami 1983). $E=$ Early; $M=$ Middle; $L=$ Late

The Imo Formation is the oldest stratigraphic unit in the inland part of the Niger Delta Basin. It consists of blue-grey clay and shale, black shale, with bands of calcareous sandstone, limestone, and marl (Reyment 1965). And, the lateral variations into sandstone facies (members) occur in some places such as Ebenebe, Umuna, and Igbabu (Reyment 1965) (Fig. 3). In western Nigeria, the Imo Formation passes partially into a thick shaly and in places, arenaceous limestone (the Ewekoro Formation; Fig. 3). In the east, the Imo Formation unconformably overlies the Nsukka Formation, outcrops at Oduenyi village extending westward through Ndiwo, and terminates at Itu-Mbuzor where it is conformably overlain by the Ameki Formation (Ikegwuonu 2015). The Ameki Formation predominantly consists of alternating shale, sandy shale, clay sandstone, and fine-grained fossiliferous sandstone, with thin bands of limestone (Reyment 1965; Arua 1986; Arua and Rao 1987). The formation is exposed at
Bende Itu-Mbuzor town extending northwestward through Ozu-Item to Uzuakoli town and terminates at Amogugu town where it is overlain by the Ogwashi Formation (Fig. 3). The Ogwashi Formation consists of alternating coarsegrained sandstone, lignite, and light-colored clays of continental origin (Kogbe 1976) (Fig. 3). The Benin Formation consists of massive coarse- to fine-grained sandstones and gravels, with minor shale intercalations. The formation is deposited in alluvial or coastal plain environments following a southward shift of the delta into a new depobelt (Doust and Omatsola 1990). The deposits become thinner offshore and disappear near the shelf edge.

\section{Materials and methods}

The materials for this study were collected through a systematic profile logging of approximately 260 -m-thick sections from the base to the top of Paleogene strata in 
the study area (Figs. 2 and 3). Twenty-seven (27) samples, distributed in the Imo Formation (12 samples), Ameki Formation (12 samples), and Ogwashi Formation (3 samples), were obtained.

The studied methods included lithologic profile logging, laboratory processing, and transmitted-light microscopy observation. The sediments were processed for palynomorph content analyses. Sample preparation was carried out using the conventional maceration technique for recovering acid-insoluble organic-walled microfossils. During sample pretreatment, the sediments were digested for $30 \mathrm{~min}$ in $40 \%$ hydrochloric acid to remove carbonates and $72 \mathrm{~h}$ in $48 \%$ hydrofluoric acid to remove silicates; oxidized for $30 \mathrm{~min}$ in $70 \% \mathrm{HNO}_{3}$ to render fossils translucent for transmitted-light microscopy observation; rinsed in $2 \% \mathrm{KOH}$ solution to neutralize the acid; swirled and stained with Safranin-O to increase contrast for identification and photography. Demineralization was not necessary for the coals and they were oxidized as with the clastic sediments.

Aliquots were dispersed with polyvinyl alcohol, dried on cover-slips and mounted in Araldite poxy resin. Five slides were made from each sample, from which a minimum of 200 grains were counted. The occurrence of each species was converted to percentage frequency, shown as: $>15 \%$ means very abundant; $10 \%-15 \%$ means abundant; $5 \%-10 \%$ means common; $1 \%-5 \%$ means occasional; and, $<1 \%$ means rare (Ikegwuonu and Umeji
2016). The recovered spores and pollen species enabled the establishment of stratigraphic distribution chart and subdivision of palynological zones (Figs. 4 and 5).

\section{Results}

The distribution of total yield of palynomorphs (terrigenous and marine species) counted per $5 \mathrm{~g}$ of the sediment shows an irregular trend with low values at the base and with increase fluctuation towards the top of the sections (Figs. 6 and 7). At the base of studied sections, values of the palynomorph yield per $5 \mathrm{~g}$ of the sediment ranged from 210 grains in sample L2/01 to 431 grains in sample L8/02 up to the sections of the Imo Formation (see Fig. 2 for reference). Towards the top of the sections, values from Location 33 of the Ogwashi Formation ranged from 383 grains in sample L33/01 to 497 grains in sample L33/03 above. In general, the maximum value throughout the studied sections was obtained in sample L23/02 at the middle of the Ameki Formation, which could be as high as 630 grains. The sample with highest total counts produced low marine and high terrigenous abundance.

The recovered palynomorph genera and species are typical of the African and South American pantropical palynoflora province, stated by Germeraad et al. (1968), to which Nigeria belongs. A total of 65 sporomorph species were identified, and the important stratigraphic index species are illustrated in Figs. 8, 9, 10.

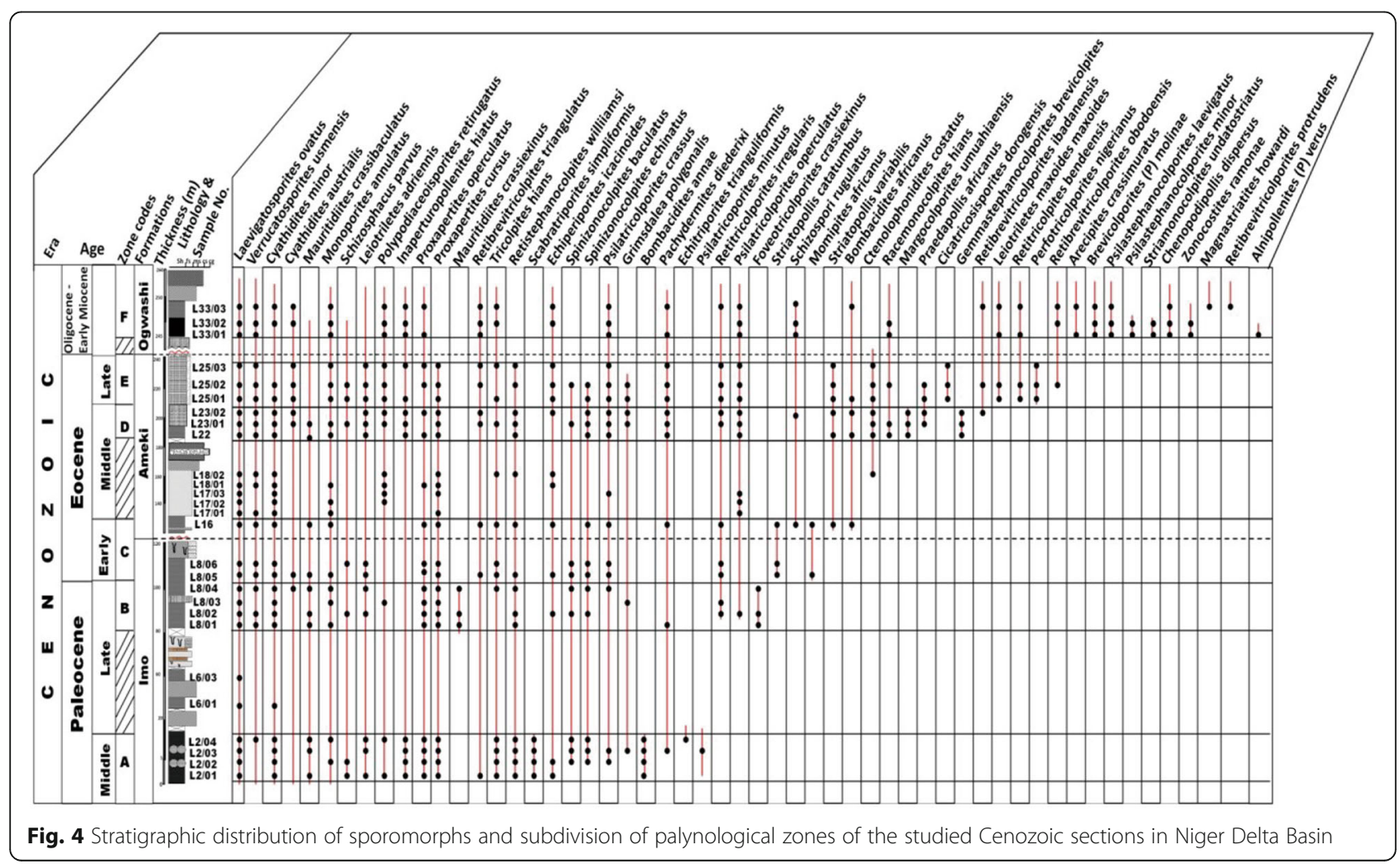




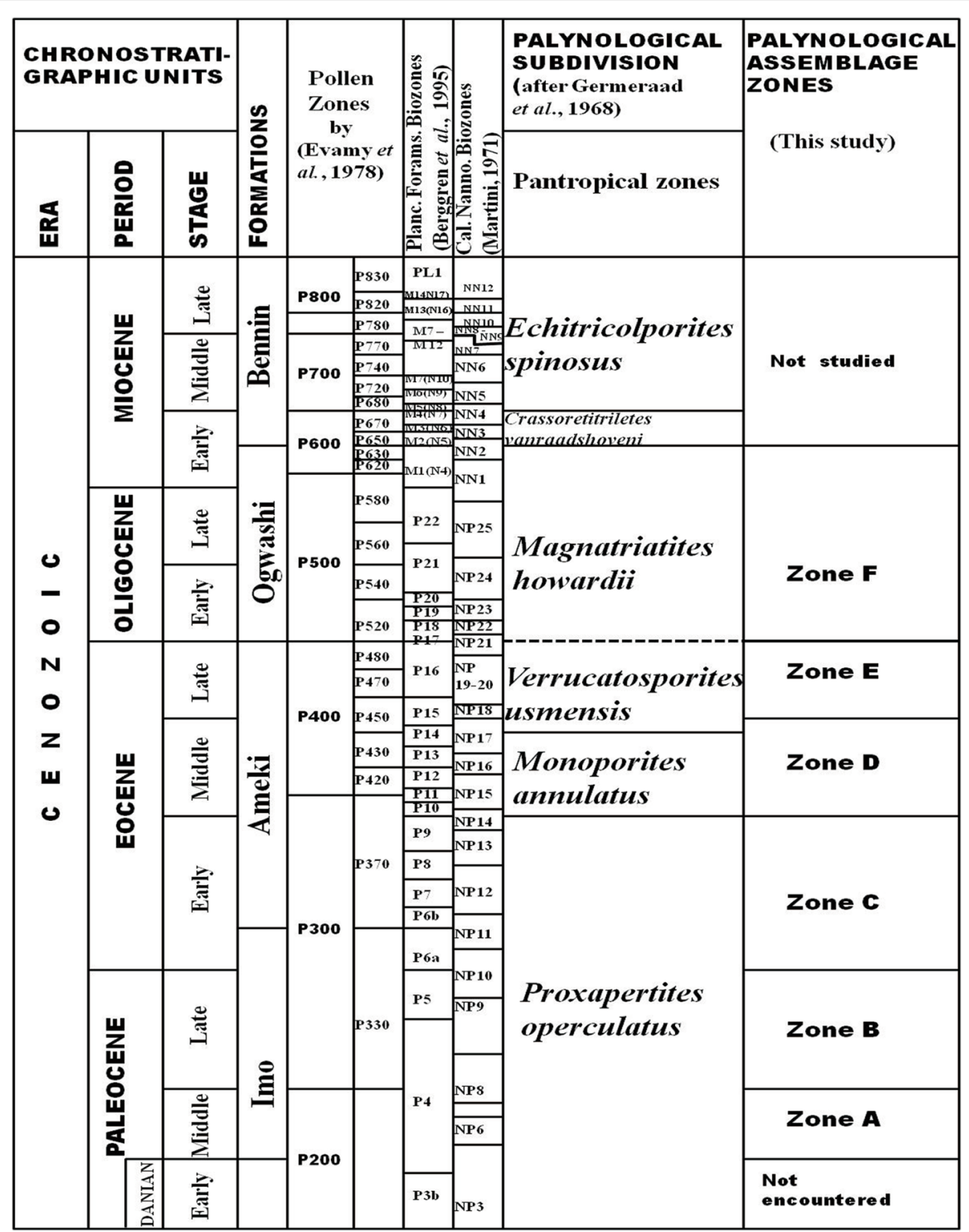

Fig. 5 Correlation chart of biozones and palynological zones of the studied Cenozoic sections in Niger Delta Basin

The monoletes, triletes, and pollen grains of inaperturates, monocolpates, tricolpates, stephanocolpates, monoporates and polyporates were identified. The important pollen genera including Proxapertites, Spinizonocolpites, Scabratriporites, Striatopollis, Bombacidites, Magnastriatites, Psilastephanocolporites and Retibrevitricolporites are also illustrated in Figs. 8, 9, 10.

\section{Discussion}

Six informal palynomorph assemblage zones, labeled A-F as their zone codes, were established based on the first and last occurrences of two or more sporomorph species (Fig. 4). The palynozones were correlated and compared with existing biozones in the subsurface, down-dip series of the Niger Delta Basin, and with the pantropical palynozones of Germeraad et al. (1968), in the tropical areas (Fig. 5). The zonal species are presented in Figs. 8, 9, 10.

\subsection{Zone A: Scabratriporites simpliformis-Bombacidites annae zone, middle Paleocene}

The palynological zone A has middle Paleocene index species such as Scabratriporites simpliformis, Bombacidites annae and Echitriporites trianguliformis. Some species of the pollen group such as Bombacidites (similar to that of extant Bombax and relatives) are characteristic of middle Paleocene-Eocene (Jaramillo and Dilcher 2000), and several of their Paleocene species have regional 


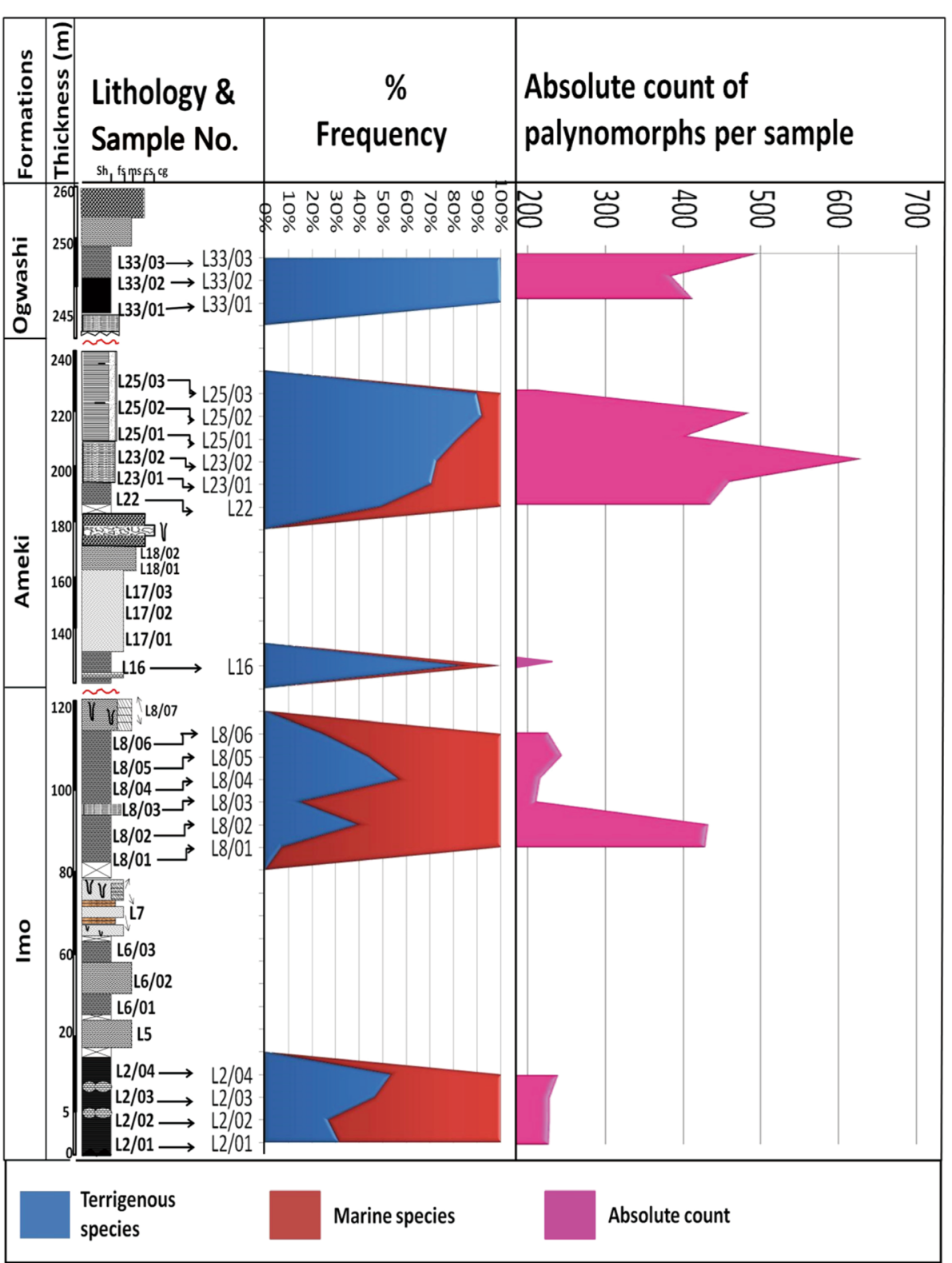

Fig. 6 Distribution of the abundance (absolute count) of marine-terrigenous species and the total yield of palynomorphs per sample in the studied sections

extinctions at the end of the Paleocene (e.g. Bombacidites annae). Here, Bombacidites annae was recorded only in this zone and was absent in the subsequent zones up the stratigraphic sequence.

The first abundance peak of the peridiniacean species, Apectodinium homomorphum (38\%), also associated with this zone. Samples L2/01 to L2/04 fall within this zone and were recognized in the carbonaceous dark shale at Loc 2 in the Imo Formation. The absence of Scabratriporites simpliformis, Bombacidites annae and Echitriporites trianguliformis in the section above sample L2/04, marks the top of this zone (Fig. 4).

\subsection{Zone B: Foveotricolporites crassiexinus-Mauritidiites} crassiexinus zone, late Paleocene

Samples of zone B were found from L8/01 to L8/04 (Fig. 4). The base was defined by the disappearance of the middle Paleocene sporomorphs assemblage Scabratriporites simpliformis, Bombacidites annae and Echitriporites trianguliformis of zone A, and the appearance of the late Paleocene Foveotricolporites crassiexinus and Mauritidiites crassiexinus. The dinoflagellate cyst assemblage from this zone includes Kallosphaeridium brevibarbatum, Apectodinium spp., Homotryblium abbreviatum, Adnatosphaeridium multispinosum, and Oligosphaeridium complex. Other rare to occasional species, 


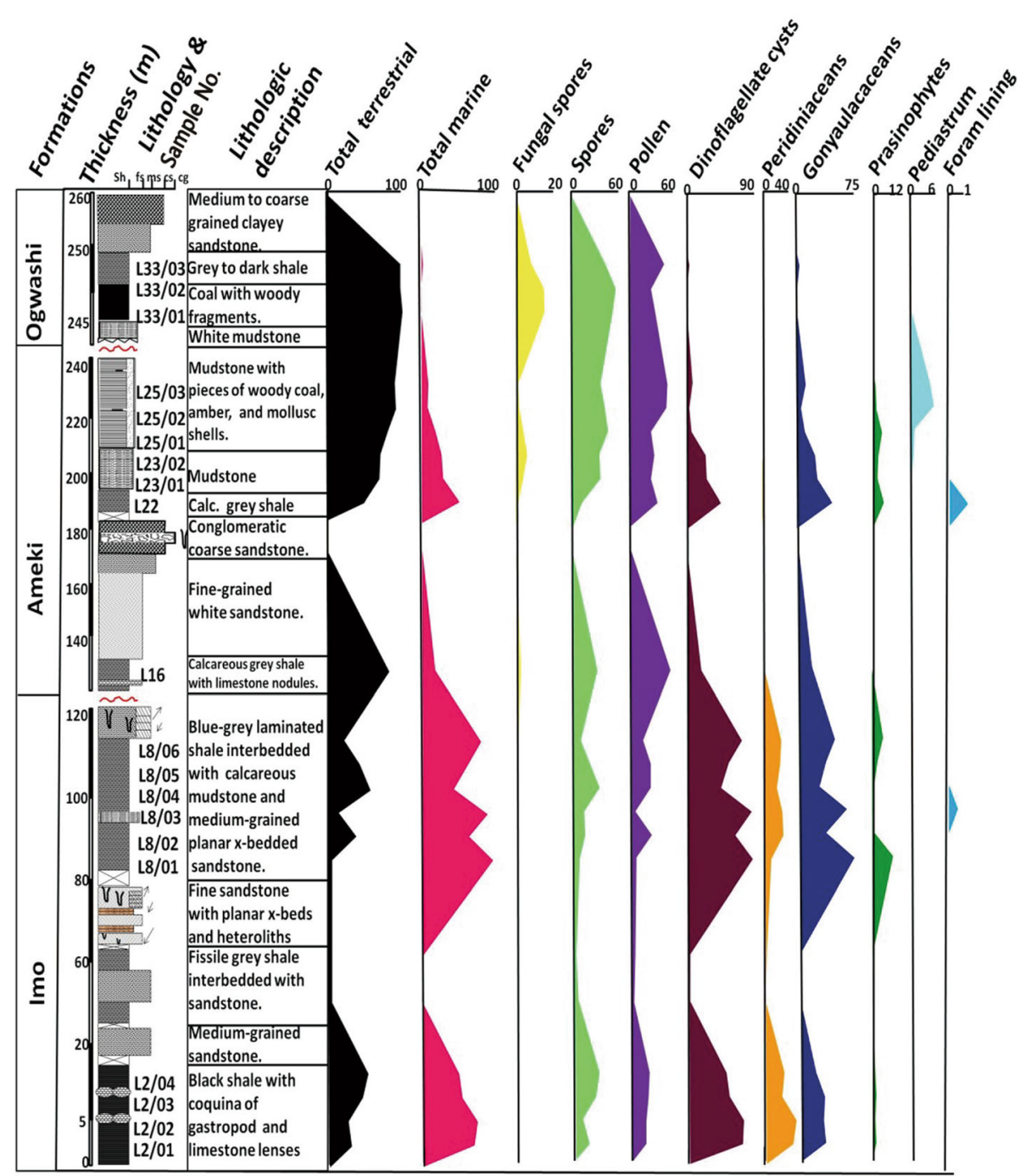

Fig. 7 Composite histogram of the studied sections and graphs of the percent frequency distribution of palynomorph groups developed in the sections

which are also confined in this zone include, Cylonephelium spinetum, Glaphyrocysta exuberans, Ifecysta spp., and Muratodinium fimbriatum.

Awad and Oboh-Ikuenobe (2016), referring to Masure et al. (1998), used the species of Apectodinium spp. and Adnatosphaeridium multispinosum to determine a late Paleocene age at the Depth of $828.70 \mathrm{~m}$ of ODP Hole 959D, in the CÔte d'Ivoire-Ghana Transform Margin. They also held that the occurrence of Ifecysta pachyderma supports an age designation of late Paleocene, which was confirmed by earlier researchers in West Africa (Jan du Chêne and Adediran 1985; Antolinez 2006; Antolinez and Oboh-Ikuenobe 2007; Bankole et al. 2007). The top of this zone was marked by the disappearance of the late Paleocene index species, Foveotricolporites crassiexinus and Mauritidiites crassiexinus.

\subsection{Zone C: Striatopollis catatumbus-Momipites africanus zone, early Eocene}

The base of zone $\mathrm{C}$ was defined by disappearance of the late Paleocene species, Foveotricolporites crassiexinus and Mauritidiites crassiexinus, and the appearance of early Eocene index species, Striatopollis catatumbus and Momipites africanus. Samples L8/05 to L16 fall within this zone (Fig. 4). Striatopollis catatumbus first occurred in early Eocene deposits in Colombia (González Guzmán 1967), Nigeria (Takahashi and Jux 1989), Venezuela (Colmenares and Teran 1993), and Qatar (El Beialy 1998). González Guzmán (1967) further remarked that the taxon also occurs in the Caribbean, and at the base of the Retibrevitricolpites triangulatus zone in Nigeria.

Towards the base of this zone, sample L8/05 marks the topmost Paleocene strata and the beginning of early Eocene deposition, i.e., the Paleocene-Eocene boundary. 


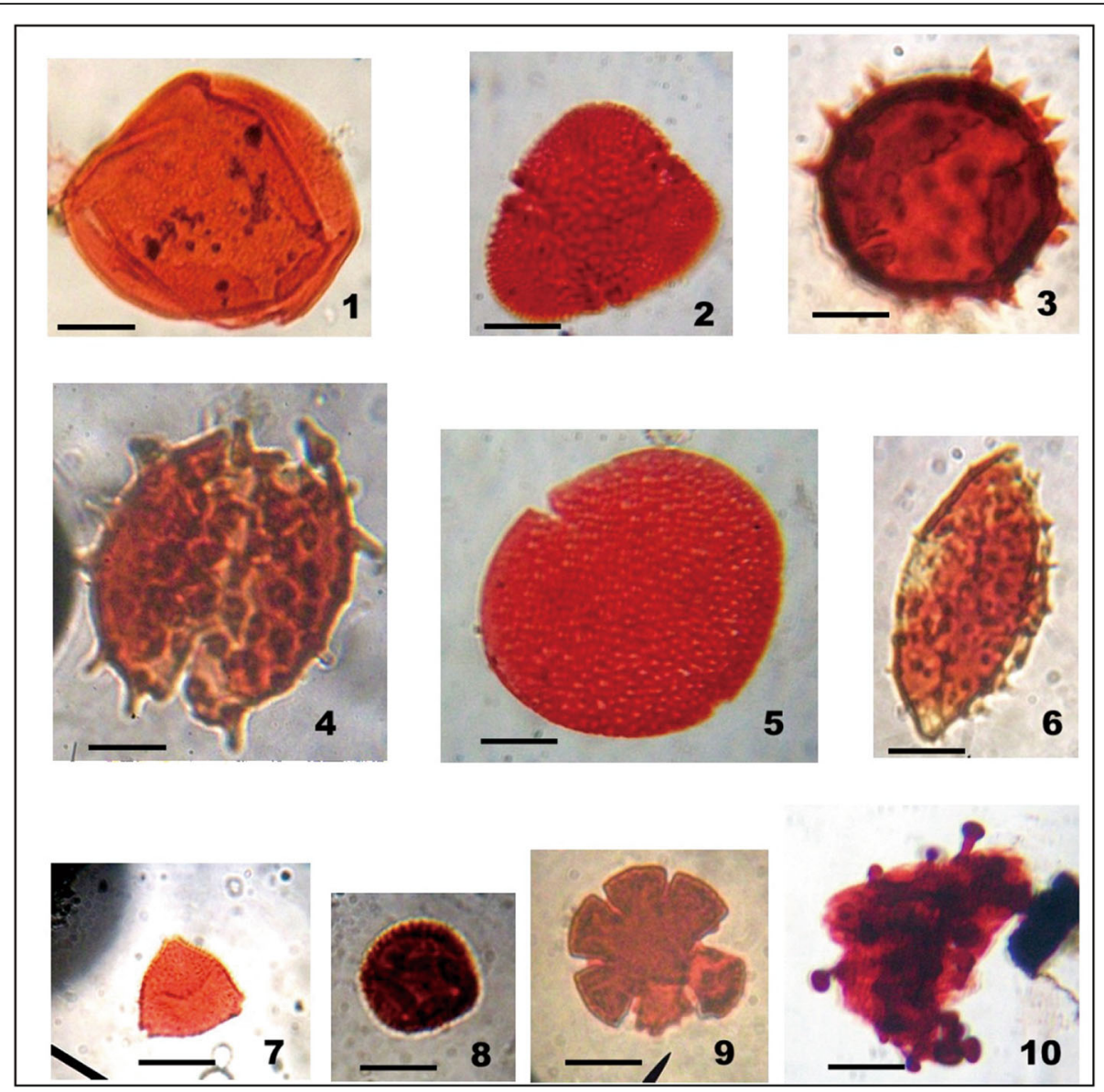

Fig. 8 Micrographs of some spores and pollen grains from the Imo Formation. 1 - Proxapertites operculatus Germeraad, Hopping and Muller 1968

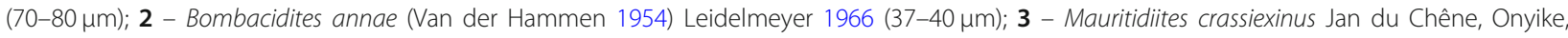
and Sowunmi 1978 (45-50 $\mu \mathrm{m}) ; \mathbf{4}$ - Spinizonocolpites baculatus Muller $1968(60 \times 55 \mu \mathrm{m}) ; \mathbf{5}$ - Proxapertites cursus Van Hoeken-Klinkenberg 1966

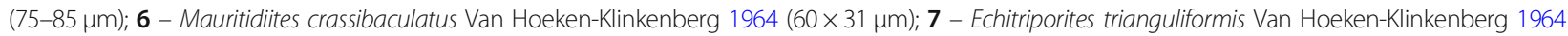
$(26 \mu \mathrm{m}) ; 8$ - Foveotricolporites crassiexinus Van Hoeken-Klinkenberg $1966(25 \times 23 \mu \mathrm{m}) ; \mathbf{9}$ - Retistephanocolpites williamsi Germeraad, Hopping and

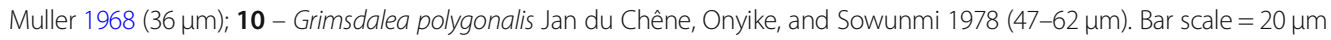

At the Paleocene-Eocene boundary, in sample L8/05, Proxapertites operculatus reaches its abundance peak (11\%); the Paleocene index species assemblage of Scabratriporites simpliformis, Bombacidites annae, Foveotricolporites crassiexinus, and Mauritidiites crassiexinus disappeared and early Eocene markers, Striatopollis catatumbus and Momipites africanus first appeared. Moreover, the percentage abundance of the dinoflagellate cyst species, Apectodinium homomorphum, remained high (15\%) across the P/E boundary. A characteristic assemblage of gonyaulacacean, Spiniferites ramosus, was commonly developed and reached its abundance peak at the top of this zone. Thus, the disappearance of the early Eocene index species in sample L17/01 above sample L16, marks the top of this zone (Fig. 4).

\subsection{Zone D: Margocolporites umuahiaensis-} Gemmastephanocolporites brevicolpites zone, middle Eocene The base of zone $\mathrm{D}$ was marked by the disappearance of early Eocene index species and the appearance of middle Eocene taxa of Margocolporites umuahiaensis and Gemmastephanocolporites brevicolpites. Samples L22 to L23/ 02 fall within this zone (Fig. 4), in which shows the abundance peak of Psilatricolporites crassus (20\%). The dinoflagellate cyst, Glaphyrocysta ordinata, also reached its abundance peak while the foraminifer linings become common. Margocolporites umuahiaensis and Gemmastephanocolporites brevicolpites were first described from middle Eocene sediments around Oba, Nnewi and Orlu areas, southeastern Nigeria (Jan du Chêne et al. 1978). The related species, Margocolporites vanwijhei, was reported by Germeraad et al. (1968) as having an EoceneOligocene age range in West Africa, Caribbean and Borneo. The top of this zone was marked by the 


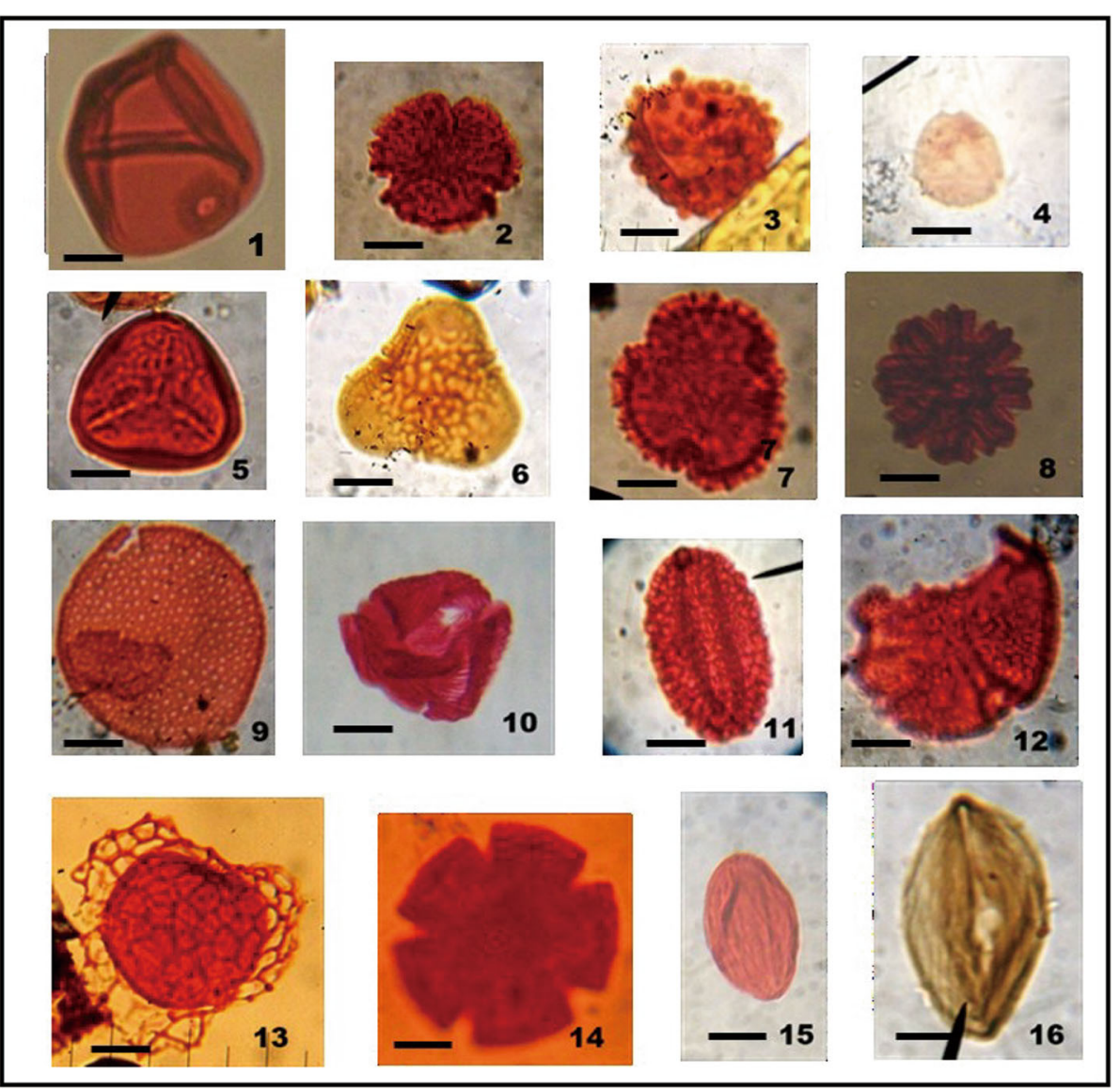

Fig. 9 Micrographs of some sporomorph species from the Ameki Formation. 1 - Monoporites annulatus Van der Hammen 1954 (34-42 $\mu$ m); 2 Retibrevitricolpites triangulatus Van Hoeken-Klinkenberg 1966 (35 $\mu \mathrm{m}) ; 3$ - Gemmastephanocolporites brevicolpites Jan du Chêne, Onyike, and

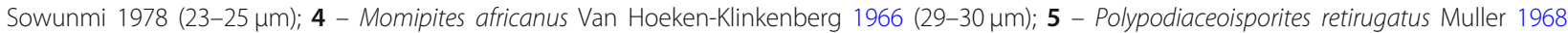

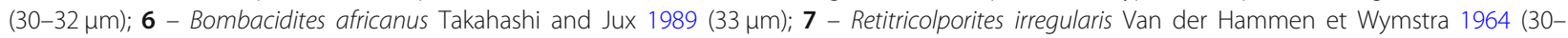

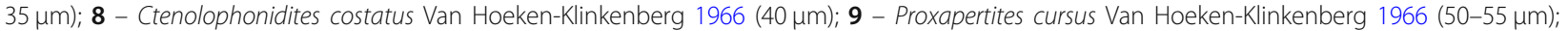
10 - Cicatricosisporites dorogensis Potonié et Gelletich $1933(25-30 \mu \mathrm{m}) ; \mathbf{1 1}$ - Perfotricolpites nigerianus Takahashi and Jux $1989(60 \times 35 \mu \mathrm{m}) ; 12$ -

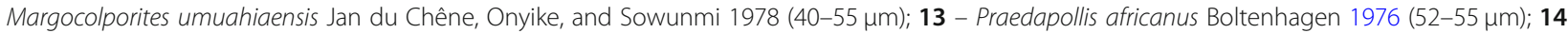

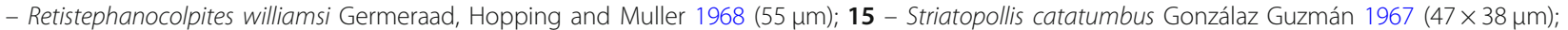
16 - Striatopollis variabilis Takahashi and Jux $1989(40 \times 25 \mu \mathrm{m})$. Bar scale $=20 \mu \mathrm{m}$

disappearance of Margocolporites umuahiaensis and Gemmastephanocolporites brevicolpites species (Fig. 4).

\subsection{Zone E: Cicatricosisporites dorogensis-Perfotricolpites nigerianus zone, late Eocene}

Samples L25/01 to L25/03 were recognized in the fossiliferous mudstone section of the Ameki Formation in Loc 25 at Isiadu-Ameke town, and fall within zone E (Fig. 4). The base of this zone was defined by the disappearance of Margocolporites umuahiaensis and Gemmastephanocolporites brevicolpites species, and the appearance of late Eocene Cicatricosisporites dorogensis and Perfotricolpites nigerianus species.

Perfotricolpites nigerianus was first reported from Middle Tertiary lacustrine deposits in the Jos Plateau (Takahashi and Jux 1989). The related species,
Perfotricolpites digitatus, was first recognized from early-middle Eocene strata of Columbia (González Guzmán 1967), and then from Oligocene strata of New Zealand (Pocknall 1982). This species was also reported by Germeraad et al. (1968) from the Caribbean and Nigeria, occurring for the first time approximately at the base of the Verrucatosporites usmensis zone (late middle Eocenelate Eocene). This taxon also has a fossil record extending into the Late Neogene of the West Coast of Africa (Partridge 1978). Moreover, Germeraad et al. (1968) held that the species of Cicatricosisporites dorogensis had initial worldwide distribution in Early Cretaceous sediments but contracted in Late Cretaceous time; and in the middle Eocene, its second expansion took place in the Caribbean and Nigeria, but declined at the end of the Oligocene Epoch. 


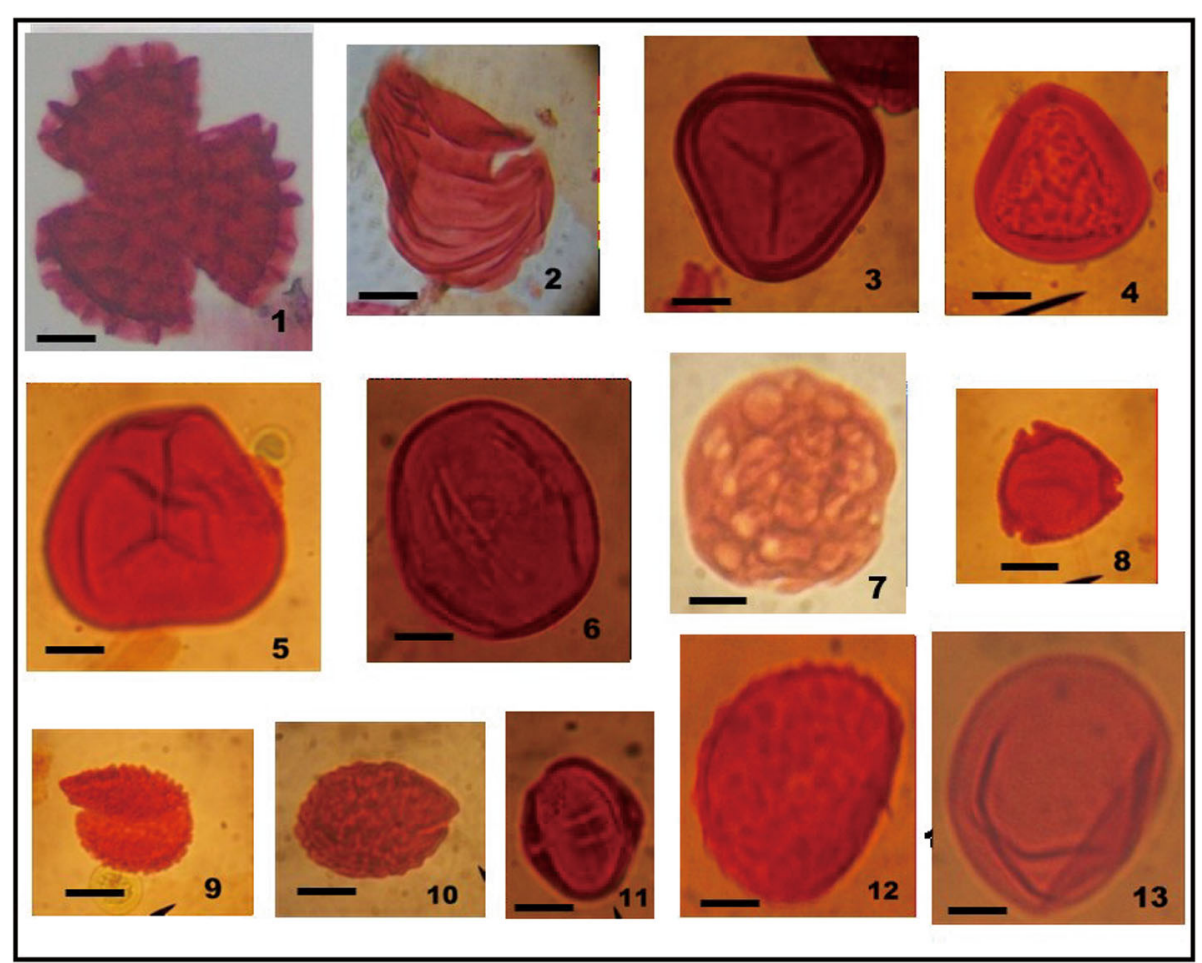

Fig. 10 Micrographs of some Oligocene-early Miocene sporomorph species. 1 - Retitricolporites irregulalis Van der Hammen et Wymstra 1964

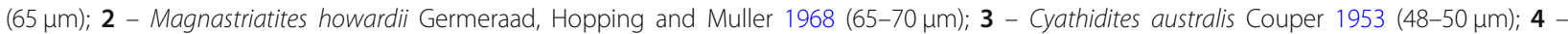
Polypodiaceoisporites retirugatus Muller $1968(45 \mu \mathrm{m}) ; \mathbf{5}$ - Leiotriletes adriennis Potonié et Gelletich, 1933 (62 $4 \mathrm{~m})$; 6 - Psilastephanocolporites laevigatus Salard-Chelboldaeff $1978(33 \times 30 \mu \mathrm{m}) ; \mathbf{7}$ - Chenopodipollis dispersus Takahashi and Jux $1989(45 \mu \mathrm{m}) ; 8$ - Retibrevitricolporites obodoensis

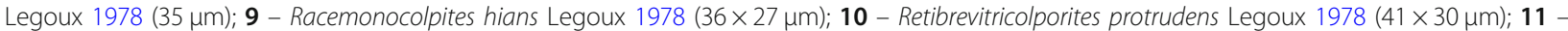
Zonocostites ramonae Germeraad, Hopping and Muller 1968 (21-24 $\mu$ m); 12 - Verrucatosporites usmensis (van der Hammen) Germeraad, Hopping

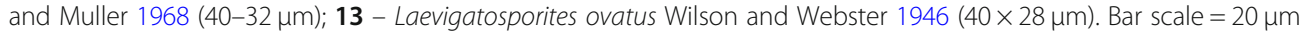

Also associated with this zone are the abundance peaks of Monoporites annulatus (11\%) and Verrucatosporites usmensis (11-18\%). The freshwater ferns, Pediastrum botryanum and P. simplex, are common. The dinoflagellate cyst, Achilleodinium biformoides, also reached its abundance peak. This zone was also characterized by the abundance and diversity of macrofaunae such as gastropod and bivalve shell fragments. The disappearance of the late Eocene Cicatricosisporites dorogensis and Perfotricolpites nigerianus, in sample L33/01 above sample L25/03, marked the top of this zone (Fig. 4).

\subsection{Zone F: Verrucatosporites usmensis-Magnastriatites howardii zone, Oligocene-early Miocene}

Samples L33/01 to L33/03 were recognized in coal and the overlying grey shale at Loc 33 in the Ogwashi Formation, and fall within zone F (Fig. 4). The base of this zone was defined by the disappearance of late Eocene Cicatricosisporites dorogensis and Perfotricolpites nigerianus, and the first appearance of Oligocene-early Miocene assemblage, Zonocostites ramonae, Retibrevitricolporites protrudens, and Magnastriatites howardii, with the abundance peak of Verrucatosporites usmensis (25\%). The rhizophora pollen, Zonocostites ramonae, was reported by Germeraad et al. (1968) to have made its first appearance during the Oligo-Miocene in the coastal and offshore marine sediments. Also, the Ceratopteris pollen (Magnastriatites howardii) made its first appearance in the Oligo-Miocene (Germeraad et al. 1968).

This zone comprises the abundance peaks of freshwater fern spore, Laevigatosporites ovatus (26\%), and fungal spore, Fusiformisporites pseudocrabbi (14\%). Other species found in this zone include Striamonocolpites undatostriatus, Psilastephanocolporites minor, Psilastephanocolporites laevigatus, Arecipites crassimuratus, Chenepodipollis dispersus, and Periporopollenites spp. This zone shows the initial appearance of dinoflagellate species, Distatodinium ellipticum. The top of this zone, however, was not encountered in this study.

\section{Conclusions}

This study documents, for the first time, the palynomorph assemblage biozonations of the up-dip areas of Paleogene strata of the Niger Delta Basin, exposed along the Bende-Umuahia axis, southeastern Nigeria. The recovered palynomorphs from the organic-rich outcrop 
samples in the study area have enabled the demarcation and establishment of six informal palynomorphs assemblage zones, labeled zone A to zone F, based on the first and/or the last occurrence of two or more species. The newly erected palynozones are correlated to other existing biozones in the subsurface series of the Niger Delta Basin, and with the pantropical palynological zones of Germeraad et al. (1968) and the palynofloral provinces of Herngreen and Chlonova (1981), in tropical areas of Africa and northern South America. Comparison of palynozones studied in southeastern Nigeria with international palynozones worldwide will assist correlation of sediments of these areas.

The results presented in this work provide a better understanding for the palynological biostratigraphy of the region as a whole. Further integrated works, especially in the aspects of foraminifers and nanofossils biostratigraphy, are required to strengthen the biozonation study for the strata in the area. And also, as work develops, further additions to the existing database will help to link the current results from the up-dip outcropping strata of the Niger Delta Basin to the results from the subsurface, to provide adequate basin-wide regional correlations.

\begin{abstract}
Acknowledgements
Authors sincerely thank Prof. C.F.R. Odumodu for his assistance during the fieldwork. We thank especially all the staff members of the Department of Geology, University of Nigeria, Nsukka, for their encouragements during the laboratory period and the microscopic stage of this study. Late Dr. (Mrs.) Ifeyinnwa Oloto is also greatly acknowledged for her useful comments and professional suggestions when this study was still in progress. The constructive feedbacks of reviewers and editors, which greatly improved the quality of this work, are well acknowledged.
\end{abstract}

\section{Authors' contributions}

$\mathrm{ONI}$ carried out the research work including laboratory and microscopic investigations; OPU supervised and provided the requisite text; OIC and KKN proofread and made useful inputs regarding the regional geology; OSN and KCC assisted in the fieldwork, proofread and made helpful suggestions on the manuscript. The consent of authorship and the order of authors have been approved by all of us. We confirm that the manuscript has been read and approved by all named authors and that there are no other persons who satisfied the criteria for authorship but are not listed.

\section{Funding}

This study forms parts of the M.Sc. degree work of the first author. No funding was received.

\section{Availability of data and materials}

All data generated or analyzed during this study are included in this published article.

\section{Competing interests}

The authors declare that they have no competing interests.

\section{Author details}

'Department of Geology, Chukwuemeka Odumegwu Ojukwu University, Uli, Nigeria. ${ }^{2}$ Department of Geology, University of Nigeria, Enugu, Nigeria. ${ }^{3}$ Department of Geology, Federal University, Oye-Ekiti, Nigeria.
Received: 18 February 2019 Accepted: 8 April 2020

Published online: 26 May 2020

\section{References}

Adebayo, O.F., A.E. Orijemie, and A.O. Aturamu. 2012. Palynology of Bog-1 well, southeastern Niger Delta basin, Nigeria. International Journal of Science and Technology 2 (4): 214-222.

Antolinez, H.J. 2006. Paleocene to early Eocene Dinoflagellate cyst biostratigraphy in Southeast Nigeria and the CÔte D'voire-Ghana transform margin (ODP site 959). Unpublished M.Sc. Thesis, 100. USA: University of Missouri-Rolla.

Antolinez, H.J., and F.E. Oboh-Ikuenobe. 2007. New species of dinoflagellate cysts from the Paleocene of the Anambra basin, Southeast Nigeria. Palynology 31: 53-62.

Arua, I. 1986. Paleoenvironment of Eocene Ameki formation of the Afikpo syncline, southern Nigeria. Journal of African Earth Sciences 5: 279-284.

Arua, I., and V.R. Rao. 1987. New stratigraphic data on the Eocene Ameki formation, southeastern Nigeria. Journal of African Earth Sciences 6: 391-397.

Aturamu, A.O., A.O. Ojo, O.F. Adebayo, and S.A. Akinyemi. 2015. Palynostratigraphic analysis of the Agbada formation (Nep-1 well) offshore, eastern Niger-Delta basin, Nigeria. British Journal of Environmental Sciences 3 (5): 19-31.

Awad, W.K., and F.E. Oboh-Ikuenobe. 2016. Early Paleogene dinoflagellate cysts from ODP hole 959D, CÔte d'Ivoire-Ghana transform margin, West Africa: New species, biostratigraphy and paleoenvironmental implications. Journal of African Earth Sciences 123: 123-144.

Bankole, S.I., E. Schrank, D. Bernd, and B.D. Erdtmann. 2007. Palynology of the Paleogene Oshosun formation in the Dahomey Basin, southwestern Nigeria. Revista Española de Micropaleontología 39: 29-44.

Boltenhagen, E. 1976. La microflore senonienne du Gabon. Revista Española de Micropaleontología 18 (4): 29-44.

Chiaghanam, O.I., K.C. Chiadikobi, O.N. Ikegwuonu, and A.O. Omoboriowo. 2014. Palynology, source rock potential and thermal maturity of Eocene Nanka formation (Ameki group) in Niger Delta basin: An investigation of Agulu Lake, southeastern Nigeria. International Organization of Scientific Research, Journal of Applied Geology and Geophysics (IOSR-JAGG) 2 (5): 87-97.

Colmenares, O.A., and L. Teran. 1993. A biostratigraphic study of Paleogene sequences in southwestern Venezuela. Palynology 17: 67-89.

Couper, R.A. 1953. Upper Mesozoic and Cainozoic spores and pollen grains from New Zealand. New Zealand Geol. Survey, Paleont. Bull 22: 77.

Doust, H., and M.E. Omatsola. 1990. The Niger Delta: Hydrocarbon potential of a major Tertiary delta province, Proceeding of KNGMG Symposium "Coastal Lowland Geology and Geotechnology" 1987, 203-212. Dordrecht: Kliwer.

Durugbo, E.U., O.T. Ogundipe, and O.K. Ulu. 2010. Palynological evidence of Pliocene-Pleistocene climatic variations from the Western Niger Delta, Nigeria. International Journal of Botany 6 (4): 351-370.

El Beialy, S.Y. 1998. Stratigraphic and palaeoenvironmental significance of Eocene palynomorphs from the Rusayl shale formation, Al Khawd, northern Oman. Review of Paleobotany and Palynology 192: 249-258.

Evamy, D.D., J. Harenboure, P. Kemerling, W.A. Knaap, F.A. Mally, and P.H. Rowlands. 1978. Hydrocarbon habitat of tertiary Niger Delta. American Association of Petroleum Geologists Bulletin 62: 1-39.

Germeraad, J.H., C.A. Hopping, and J. Muller. 1968. Palynology of tertiary sediments from tropical areas. Reviews of Paleobotany and Palynology 6: 189-343.

González Guzmán, A.E. 1967. A palynological study on the upper los Cuervos and Mirador formations (lower and middle Eocene, Tibú area, Colombia). University of Amsterdam, E. J. Brill, Leiden, 129 pp.

Herngreen, G.F.W., and A.F. Chlonova. 1981. Cretaceous microflora provinces. Pollen et Spores 23: 241-555.

Ige, O.E. 2009. A late tertiary pollen record from Niger Delta, Nigeria. International Journal of Botany 5: 203-215.

Ikegwuonu, O.N. 2015. Middle Paleocene to Early Miocene Palynostratigraphy of sediments in Bende-Umuahia area, Niger Delta, basin, southeastern Nigeria, Unpublished M.Sc. Thesis, Department of Geology, University of Nigeria Nsukka, p. 45. 
Ikegwuonu, O.N., and O.P. Umeji. 2016. Palynological age and paleoenvironment of deposition of mid-Cenozoic sediments around Umuahia Niger Delta, southeastern Nigeria. Journal of African Earth Sciences 117 (29): 160-170.

Jan du Chêne, R.E., and S.A. Adediran. 1985. Late Paleocene to early Eocene dinoflagellates from Nigeria. Cahiers de Micropaleontologie 3: 5-39.

Jan du Chêne, R.E., M.S. Onyike, and M.A. Sowunmi. 1978. Some new Eocene pollen of the Ogwashi-Asba formation, south-eastern Nigeria. Revista Española de Micropaleontología 10 (2): 285-322.

Jaramillo, C.A., and D.L. Dilcher. 2000. Microfloral diversity patterns of the late Paleocene-Eocene interval in Colombia, northern South America. Geology 28 (9): 815-818.

Kogbe, C.A. 1976. The cretaceous and Paleogene sediments of southern Nigeria. In Geology of Nigeria, ed. C.A. Kogbe, 237-252. Ibadan: Elizabethan Publishing Company.

Legoux, O. 1978. Quelques especes de pollen caracteristitiques au Neogene du Nigeria Bulletin Centres. Recherches Exploration-Prod Elf Aquitaine 1 (2): 265-317.

Leidelmeyer, P. 1966. The Paleocene and lower Eocene pollen flora of Guyana. Mededelingen Rijks Geologische Dienst 38: 49-70.

Lucas, F.A., and E. Ishiekwene. 2010. Miospore (pollen and spore) biozonation model for late cretaceous-tertiary succession of Gbekebo-I well, Benin flank, Anambra Basin Nigeria. World Journal of Applied Science and Technology 2 (2): 303-308.

Martini, E. 1971. Standard tertiary and quaternary calcareous nannoplankton zonation. In Proceedings of the $2^{\text {nd }}$ Planktonic Conference, vol. 2, 739-785.

Masure, E., R. Rauscher, J. Dejax, M. Schuler, and B. Ferre. 1998. CretaceousPaleocene palynology from the CÔte d'Ivoire-Ghana transform margin, sites 959, 960, 961, and 962. In Proceedings of the Ocean Drilling Program, Scientific Results, vol. 159, 253-276.

Muller, J. 1968. Palynology of the Pedawan and plateau sandstone formations (cretaceous-Eocene) in Sarawak. Micropaleontology 14: 1-37.

Murat, R.C. 1972. Stratigraphy and paleogegraphy of the cretaceous and lower tertiary in southern Nigeria. In African geology, ed. T.F.J. Dessauvagie and A.J. Whiteman. Ibadan: University of Ibadan.

Oboh, F.E. 1995. Sedimentological and palynological characteristics of the E2.0 reservoir (middle Miocene) in the Kolo Creek field, Niger Delta. In Geology of deltas, ed. M.N. Oti and G. Postma, 243-256. Rotterdam: Balkema Publishers.

Oboh, F.E., M.B. Salami, and J.L. Chapman. 1992. Palynological interpretation of the palaeo-environments of Miocene strata of the well Igbomotoru-1, Niger Delta. Journal of Micropalaeontology 11: 1-6.

Oboh-lkuenobe, F.E., G.C. Obi, and C.A. Jaramillo. 2005. Lithofacies, palynofacies and sequence stratigraphy of Paleogene strata in southeastern Nigeria. Journal of African Earth Sciences 41: 75-100.

Ojo, A.O., and O.F. Adebayo. 2001. Miospore biostratigraphy of the Agbada formation in the eastern Niger Delta basin. The Journal of Technoscience 5: $28-42$.

Ojo, A.O., and M.B. Salami. 1992. Biostratigraphy of Niger delta (abstracts). Nigerian Mining and Geosciences Society Programme and Abstracts, 121.

Okeke, K.K., and O.P. Umeji. 2016. Palynostratigraphy, palynofacies and palaeoenvironment of deposition of Selandian to Aquitanian sediments, southeastern Nigeria. Journal of African Earth Sciences 117: 160-170.

Omatsola, M.E., and O.S. Adegoke. 1981. Tectonic evolution and cretaceous stratigraphy of the Dahomey Basin. Journal of Mining and Geology 18 (1): 130-137.

Partridge, A. 1978. Palynology of the late tertiary sequence at site 365, Leg 40, Deep Sea Drilling Project. In: Bolli, H.M. (Ed.). vol. 40, pp. 953-961.

Pocknall, D.T. 1982. Palynology of late Oligocene Pomahaka estuarine bed sediments, Waikoikoi, Southland, New Zealand. New Zealand Journal of Botany 20: 263-287.

Potonié, R., and J. Gelletich. 1933. Über Pteridophytensporen einer eocänen Braunkohle aus Dorog in Ungarn. Sitz. Gesell. Naturforsch Freunde Berlin 33: $517-526$

Reijers, T.J.A., S.W. Petters, and C.S. Nwajide. 1997. The Niger Delta Basin. In African basins, ed. R.C. Selley, 151-172. Amsterdam: Elsevier.
Reyment, R.A. 1965. Aspects of the geology of Nigeria, 144. Ibadan: University Press.

Salami, M.B. 1983. Some late cretaceous and early tertiary pteridophytic spores from southern Nigerian sedimentary basin. Revista Española de Micropaleontología 15 (2): 257-272.

Salard-Chelboldaeff, M. 1978. Sur la palynoflora Maestrichtienne et Tertiaire du Bassin sedimentaire littoral du Cameroun. Pollen et Spores 20 (2): 215-260.

Short, K.C., and A.J. Stauble. 1967. Outline of geology of Niger Delta. AAPG Bulletin 51 (5): 761-779.

Sowunmi, M.A. 1987. Palynological studies in the Niger Delta. In The early history of the Niger Delta, ed. E.J. Alagoa, F.N. Anozie, and N. Nzewunwa, 29-59. United Kingdom: Helmat Buske Verlag Hamburg.

Takahashi, K., and U. Jux. 1989. Palynology of middle tertiary lacustrine deposits from the Jos plateau, Nigeria. Bull. Fac. of Liberal Arts, Nagasaki University, (Natural Sciences) 29 (2): 181-367.

Umeji, O.P. 2002. Mid-tertiary (late Eocene-Early Miocene) age of lignites from Mpu formation of Abakaliki Basin, southeastern Nigeria. Journal of Mining and Geology 38 (2): 111-117.

Umeji, O.P. 2003. Palynological data from the road section at the Ogbunike toll-gate, Onitsha, southeastern Nigeria. Journal of Mining and Geology 39 (2): 95-102.

Umeji, O.P., and C.S. Nwajide. 2014. Record of warm temperate pollen from the Paleogene-Neogene lignite of Southeast Nigeria: Consequences of regional paleoclimatic changes or tectonics? Quaternary International 338: 2-13.

Van der Hammen, T. 1954. El desarrollo de la flora Colombiana en los periodos geologicos, i. Maastrichtiano hasta Tercia rio mas inferior. Bulletin of Geology, Ingeominas, Bogota 2 (1): 49-106.

Van der Hammen, T., and T.A. Wymstra. 1964. A palynological study of the tertiary and upper cretaceous of British Guiana. Leidse Geologische Mededelingen 30: 183-241.

Van Hoeken-Klinkenberg, P.M.J. 1964. A palynological investigation of some upper cretaceous sediments in Nigeria. Pollen et Spores 6 (1): 290-231.

Van Hoeken-Klinkenberg, P.M.J. 1966. Maastrichtian, Paleocene and Eocene pollen and spores from Nigeria. Leidse Geologische Mededelingen 38: 37-48.

Wilson, L.R., and R.M. Webster. 1946. Plant microfossils from a fort union coal of Montana. American Journal of Botany 33 (4): 271-278.

\section{Publisher's Note}

Springer Nature remains neutral with regard to jurisdictional claims in published maps and institutional affiliations.

\section{Submit your manuscript to a SpringerOpen ${ }^{\circ}$ journal and benefit from:}

- Convenient online submission

- Rigorous peer review

- Open access: articles freely available online

- High visibility within the field

- Retaining the copyright to your article

Submit your next manuscript at $\boldsymbol{\nabla}$ springeropen.com 